University of Nebraska - Lincoln

DigitalCommons@University of Nebraska - Lincoln

Publications from USDA-ARS / UNL Faculty

U.S. Department of Agriculture: Agricultural

Research Service, Lincoln, Nebraska

2017

\title{
Mountain Gem Russet: a Potato Variety with High Early and Full Season Yield Potential and Excellent Fresh Market and Early Processing Characteristics
}

\author{
J. C. Stark \\ University of Idaho, jstark@uidaho.edu \\ R. G. Novy \\ USDA-ARS, Rich.Novy@ars.usda.gov
}

J. L. Whitworth

USDA-ARS, jonathan.whitworth@ars.usda.gov

N. R. Knowles

Washington State University, rknowles@wsu.edu

M. J. Pavek

Washington State University, mjpavek@wsu.edu

See next page for additional authors

Follow this and additional works at: https://digitalcommons.unl.edu/usdaarsfacpub

Stark, J. C.; Novy, R. G.; Whitworth, J. L.; Knowles, N. R.; Pavek, M. J.; Thornton, M.; Spears, R.; Brown, C. R.; Charlton, B. A.; Sathuvalli, V.; Yilma, S.; Olsen, N.; and Brandt, T. L., "Mountain Gem Russet: a Potato Variety with High Early and Full Season Yield Potential and Excellent Fresh Market and Early Processing Characteristics" (2017). Publications from USDA-ARS / UNL Faculty. 1789.

https://digitalcommons.unl.edu/usdaarsfacpub/1789

This Article is brought to you for free and open access by the U.S. Department of Agriculture: Agricultural Research Service, Lincoln, Nebraska at DigitalCommons@University of Nebraska - Lincoln. It has been accepted for inclusion in Publications from USDA-ARS / UNL Faculty by an authorized administrator of DigitalCommons@University of Nebraska - Lincoln. 


\section{Authors}

J. C. Stark, R. G. Novy, J. L. Whitworth, N. R. Knowles, M. J. Pavek, M. Thornton, R. Spears, C. R. Brown, B. A. Charlton, V. Sathuvalli, S. Yilma, N. Olsen, and T. L. Brandt 


\title{
Mountain Gem Russet: a Potato Variety with High Early and Full Season Yield Potential and Excellent Fresh Market and Early Processing Characteristics
}

\author{
J. C. Stark ${ }^{1}$ • R. G. Novy ${ }^{2}$ • J. L. Whitworth ${ }^{2}$ - N. R. Knowles ${ }^{3}$ • M. J. Pavek ${ }^{3}$ • \\ M. Thornton ${ }^{4}$ R. Spear ${ }^{5}$ C. R. Brown ${ }^{6}$ B. A. Charlton ${ }^{7}$ V. Sathuvalli ${ }^{8}$ - S. Yilma ${ }^{9}$. \\ N. Olsen ${ }^{10}$ - T. L. Brandt ${ }^{10}$
}

Published online: 22 December 2015

This document is a U.S. government work and

(C) The Potato Association of America 2015

\begin{abstract}
Mountain Gem Russet is a potato variety notable for having both high early and full-season yields of oblonglong, medium-russeted tubers with higher protein content than those of standard potato varieties. Mountain Gem Russet has greater resistance to soft rot, tuber late blight, growth cracks and second growth than Russet Burbank. Mountain Gem Russet produced greater total and U.S. No. 1 yields than Ranger Russet and Russet Norkotah in early-season trials conducted in Idaho, Oregon and Washington over a 3 year period. In full-season trials conducted in five western states over a 4 year period, average total and U.S. No. 1 yields for Mountain
\end{abstract}

J. C. Stark

jstark@uidaho.edu

1 Idaho Falls R\&E Center, University of Idaho, Idaho Falls, ID 83402-1575, USA

2 U.S. Department of Agriculture (USDA)-Agricultural Research Service (ARS), Aberdeen R\&E Center, Aberdeen, ID 83210, USA

3 Washington State University, Pullman, WA 99164, USA

4 Southwest Idaho R\&E Center, University of Idaho, Parma, ID 83660 , USA

5 McCain Foods, Burley, ID 83318, USA

6 USDA/ARS, Prosser, WA 99350, USA

7 Klamath Basin R\&E Center, Oregon State University, Klamath Falls, OR 97603, USA

8 Hermiston Agricultural R\&E Center, Oregon State University, Hermiston, OR 97838, USA

9 Oregon State University, Corvallis, OR 97331, USA

10 Kimberly R \& E Center, University of Idaho, Twin Falls, ID 83341, USA
Gem Russet were almost always higher than Ranger Russet and Russet Burbank, with specific gravities averaging between these two standard cultivars. It maintains acceptable reducing sugar concentrations and fry quality when stored at $8.9^{\circ} \mathrm{C}$ and has displayed a high level of fry color uniformity from tuber stem to bud end providing good potential for early processing. High fresh merit ratings and taste panel sensory scores comparable to Russet Burbank indicate good fresh market potential for Mountain Gem Russet. It was released in 2015 by the USDA-ARS and the Agricultural Experiment Stations of Idaho, Oregon, and Washington, and is a product of the Pacific Northwest Potato Variety (Tri-State) Development Program.

Resumen Mountain Gem Russet es una variedad de papa notable por tener altos rendimientos en ambos ciclos, el temprano y el completo, de tubérculos oblongos largos, medianos corrugados, con más alto contenido de proteína que el de variedades de papa estándar. Mountain Gem Russet tiene mayor resistencia a la pudrición blanda, al tizón tardío del tubérculo, a deformaciones de tubérculo y a la mayoría de los defectos internos y externos que Russet Burbank. Mountain Gem Russet produjo más rendimientos totales y U.S. 1 que Ranger Russet y Russet Norkotah en ensayos de ciclo temprano conducidos en Idaho, Oregon y Washington en un período de tres años. En ensayos de ciclo completo desarrollados en cinco Estados del oeste en un período de cuatro años, el promedio de los rendimientos totales y de U.S. 1 para Mountain Gem Russet fueron casi siempre más altos que Ranger Russet y Russet Burbank, con gravedades específicas promediando entre estas dos variedades estándar. Mantiene concentraciones aceptables de azucares reductores y calidad de freído cuando se almacena a $8.9^{\circ} \mathrm{C}$ y ha exhibido un alto nivel de uniformidad en el color del freído desde la base hasta el extremo apical, aportando buen potencial para 
proceso temprano. Altos rendimientos totales y de U.S. 1 tempranos y tardíos, aunados con excelentes cualidades culinarias y nutricionales, hacen de Mountain Gem Russet una excelente candidata también para la producción de mercado fresco. Se liberó en el 2015 por el USDA-ARS y las Estaciones Agrícolas Experimentales de Idaho, Oregon y Washington, y es un producto del Programa de Desarrollo de Variedades de Papa del Pacífico Noroccidental (Tri-State).

Keywords Solanum tuberosum · Variety · Breeding · Processing

\section{Introduction}

Mountain Gem Russet is a product of the cooperative USDA/Agricultural Research Service (ARS) and University of Idaho potato breeding and varietal development program in Aberdeen, Idaho. It resulted from a hybridization between parental breeding clones A98292-2 and A98104-4 conducted in 2003 by ARS personnel (Fig. 1). Parental breeding clones were both early maturing and were crossed with one another for the generation of early maturing, russet-skinned progeny. The high yields observed in Mountain Gem Russet were contributed by A98292-2 with the attractive tuber type and common scab resistance of Mountain Gem Russet derived from A98104-4.

True potato seed of the hybridization was planted and germinated in 2006, with Mountain Gem Russet selected in the field from a single hill trial at Tetonia, Idaho in 2007. Selection of Mountain Gem Russet was based on its large tuber size and acceptable type under the short growing season at that site (vine kill occurring approximately 90 days after planting). Mountain Gem Russet was then grown in 6-hill and 12-hill plots at Aberdeen and Tetonia, Idaho, respectively in 2008, and from 2009 through 2010 in replicated yield trials at Aberdeen, Idaho. It was entered in the Tri-State Variety Trials in Idaho, Oregon, and Washington in 2011, and subsequently advanced to the Western Regional Potato Variety Trials where it was evaluated in California, Colorado, Idaho, Oregon, and Washington in 2012 through 2014.

The release was be made jointly by the USDA/ARS and the experiment stations of Idaho, Washington, and Oregon, which represent the institutions that comprise the Northwest (Tri-State) Potato Variety Development Program.

\section{Varietal Description}

Plant and tuber descriptions were obtained from field evaluations conducted in 2012-2013 at Aberdeen, ID (Fig. 2).

\section{Plants (Fig. 2a, b and c)}

Growth habit: medium sized, erect vine expressing medium to late maturity (115 days from planting to harvest, compared with 125 days for Russet Burbank). Vine architecture is intermediate to closed with stems hardly visible. Stems: moderately thick, medium green with weak red-purple anthocyanin pigmentation, and medium prominent wings ( $\sim 2 \mathrm{~mm}$ wide). Leaves: large-sized, green color (Royal Horticulture Society Color Chart, RHSCC green137B), with a medium open silhouette, and absent red-purple anthocyanin pigmentation on the petioles and midribs. Terminal leaflets: Broadly ovate shape with acuspidate tip and cordate base; slightly wavy margins; average length $76 \mathrm{~mm}$, width $51 \mathrm{~mm}$ (average of 80 mid-canopy leaflets). Primary leaflets: $3-5$ pairs with an average of 4.0 pairs; medium ovate with a cuspidate tip and cordate base. Secondary
Fig. 1 Pedigree of Mountain Gem Russet (A03158-2TE)

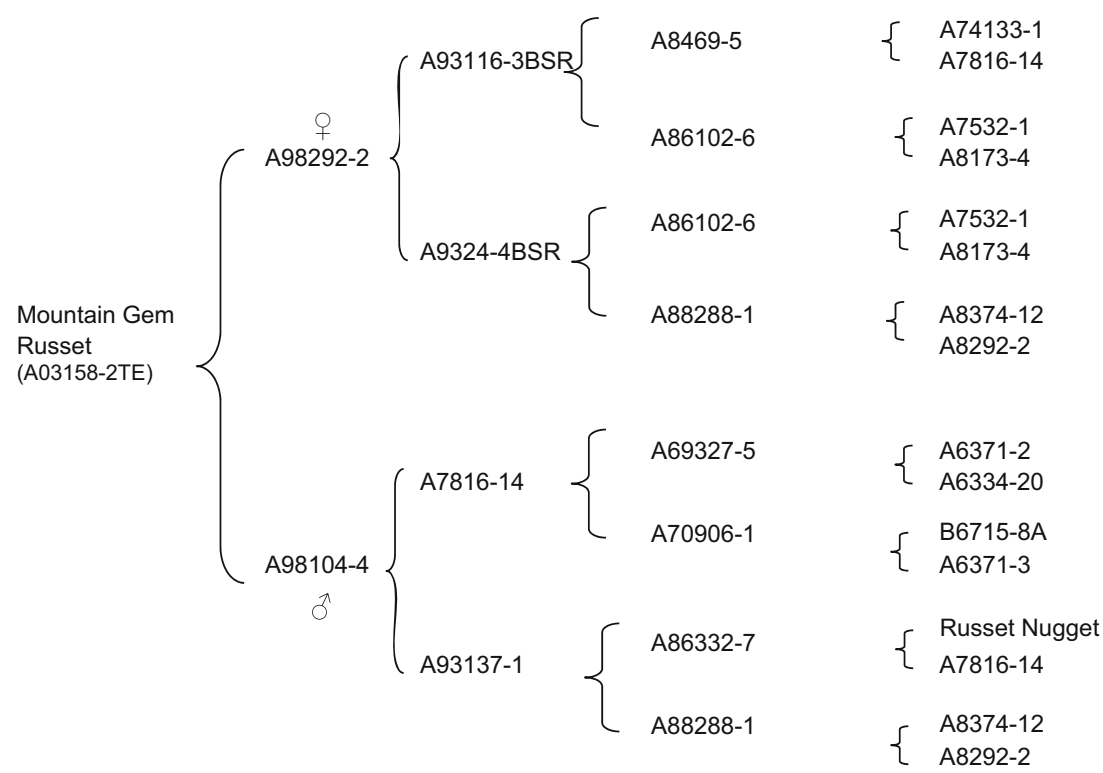


leaflets: $2-4$ pairs, average 3.8 pairs. Tertiary leaflets: $2-5$ pairs, average of 3.4 pairs. Stipules: large non-clasping.

\section{Flowers (Fig. 2d)}

Flowers are relatively abundant in number, averaging 16.0 florets per inflorescence and 6.4 inflorescences per plant. Buds: anthocyanin pigmentation is weak and purplish-red in color; minimal pedicel articulation. Calyx: sepals long, awl-shaped, fused to one-fourth the length of the bud. Corolla: pentagonal shape; white color (RHSCC white $155 \mathrm{~A}$ on the inside surface, white $155 \mathrm{~A}$ on the outside), medium-sized, averaging $33 \mathrm{~mm}$ diameter as measured from corolla tips. Anthers: yellowish-orange (RHSCC yellow-orange14A) color; arranged as a narrow cone. Stigma: capitate, yellowish-green (RHSCC yellowgreen146A) color. Pollen: low production of pollen, with successful use as a male parent in hybridizations. Berries: very low production in the field.

\section{Tubers (Fig. 2e)}

Long; similar in shape to Russet Burbank; medium thick; mean length $119 \mathrm{~mm}$, range 87 to $160 \mathrm{~mm}$; mean width $61 \mathrm{~mm}$, range 44 to $75 \mathrm{~mm}$; mean thickness $54 \mathrm{~mm}$, range 43 to $70 \mathrm{~mm}$ (average of 80 tubers weighing 168 to $336 \mathrm{~g}$ ). Skin: tan to light brown (RHSCC grayed-orange 164B) color; with a medium russet pattern. Eyes: intermediate in depth with a slightly prominent eyebrow; evenly distributed; high number of eyes per tuber, mean 25 , range 17 to 34 . Flesh: light cream colored (RHSCC yellow-white 158D). Dormancy: short, approximately 90 days when stored at $7{ }^{\circ} \mathrm{C}$.

\section{Light sprouts (Fig. 2f)}

Red-violet anthocyanin pigmentation on both the base and tip; ovoid base; closed bud scales; medium hirsute base and moderately strong hirsute bud scales; moderate number of large root initials.
Fig. 2 Mountain Gem Russet (a) field plants compared to Russet Burbank, (b) plant, (c) leaf, (d) inflorescence, (e) external and internal tuber appearance, and (f) light sprouts on tuber
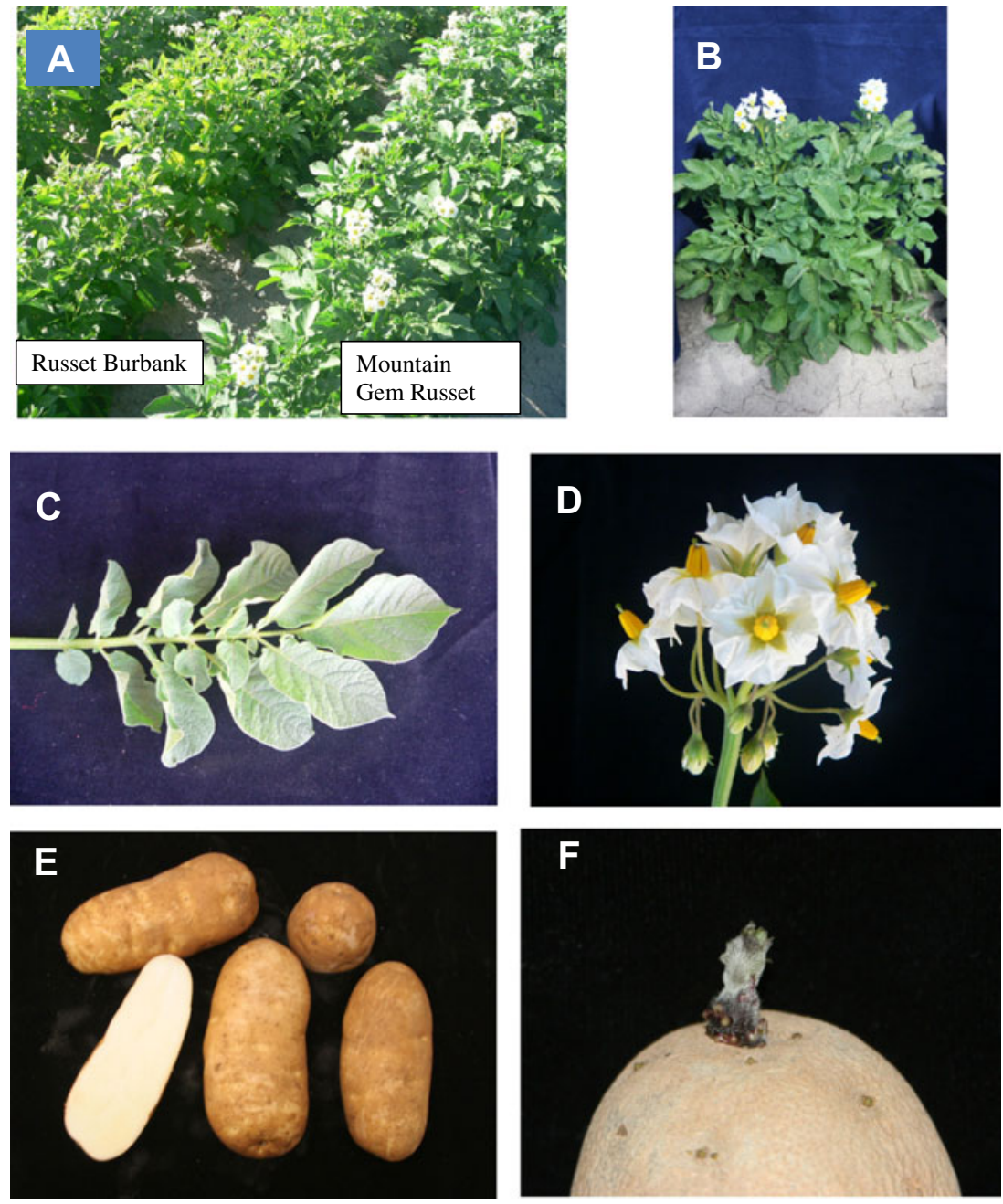


\section{Agronomic Performance}

Total yield for Mountain Gem Russet in 6 irrigated, fullseason trials conducted in southern Idaho in 2012-2014 was significantly higher than Ranger Russet, Russet Burbank and Russet Norkotah (Table 1). U.S. No. 1 yield (using the USDA Potato Grading Standard for U.S. No. tubers, defined as tubers with diameters greater than $48 \mathrm{~mm}$ and less than $5 \%$ internal and external defects) for Mountain Gem Russet was substantially higher than the three standard cultivars, averaging $11.3 \mathrm{mt} / \mathrm{ha}$ higher than Ranger Russet, $25.1 \mathrm{mt} / \mathrm{ha}$ higher than Russet Burbank and $22.6 \mathrm{mt} / \mathrm{ha}$ higher than Russet Norkotah. Percent U.S. No. 1 tubers averaged $80 \%$, which was significantly higher than any of the other standard varieties tested in these trials except Russet Norkotah. Mountain Gem Russet produced a higher proportion of large $(>341 \mathrm{~g})$ tubers and fewer small tubers $(<114 \mathrm{~g})$ than Russet Burbank and Russet Norkotah as well as a relatively small percentage of cull tubers. Tuber size distribution of Mountain Gem Russet did not differ appreciably from that of Ranger Russet.

Total and U.S. No. 1 yields of Mountain Gem Russet in early-season, irrigated trials conducted in Idaho, Oregon and Washington in 2011-2014 were higher than Ranger Russet and Russet Norkotah in all three states (Table 2). The percentage of total yield for Mountain Gem Russet that could be categorized as U.S. No. 1 yield was similar to or greater than Ranger Russet and Russet Norkotah in all three states. Specific gravities of Mountain Gem Russet in these early season trials were lower than those for Ranger Russet but comparable to or greater than Russet Norkotah.

Mountain Gem Russet was evaluated in 15 full-season trials conducted in Idaho, Oregon and Washington during 2011-2014 as part of the Tri-State and Western Regional Variety Trial Programs. Average total yield for Mountain Gem Russet was higher than Ranger Russet and Russet Burbank except for Russet Burbank at the Oregon site (Table 3). However, U.S. No. 1 yield and percent U.S. No. 1 tubers for Mountain Gem Russet were significantly higher than the standard cultivars at all sites. Tuber specific gravity for Mountain Gem Russet was higher than Russet Burbank but lower than Ranger Russet.

Mountain Gem Russet was evaluated for 4 years in the full-season Western Regional Potato Variety Trials, conducted in Idaho, Oregon, Washington, Colorado and California. In these trials, Mountain Gem Russet produced higher average total yield than Ranger Russet at all locations and higher total yield than Russet Burbank at all locations but Oregon (Table 4). Averaged across all 7 locations, total yield for Mountain Gem Russet was $9 \%$ higher than Ranger Russet and $14 \%$ higher than Russet Burbank. U.S. No. 1 yield for Mountain Gem Russet was higher than the two standard cultivars at all locations, with overall mean yield exceeding Ranger Russet by $18 \%$ and Russet Burbank by $45 \%$. Percent U.S. No. 1 tubers were also higher for Mountain Gem Russet at all locations. Mean specific gravity for Mountain Gem Russet in the Western Regional Trials was similar to Russet Burbank and lower than Ranger Russet.

Table 1 Average total yield, U.S. No. 1 yield, percent U.S. No. 1, specific gravity, tuber size distribution, and French fry color of Mountain Gem Russet, Ranger Russet, Russet Burbank, and Russet

Norkotah from 6 irrigated, full-season yield trials (125-135 day growing seasons) conducted at Aberdeen, and Kimberly, Idaho ${ }^{\text {a }}$

\begin{tabular}{|c|c|c|c|c|c|c|c|c|c|c|c|}
\hline \multirow[t]{2}{*}{ Cultivar } & \multicolumn{2}{|c|}{ Yield (mt/ha) } & \multirow[t]{2}{*}{$\%$ No. 1} & \multirow[t]{2}{*}{ Specific gravity ${ }^{\mathrm{b}}$} & \multicolumn{5}{|c|}{ Tuber size distribution as percent of total yield } & \multicolumn{2}{|c|}{ Fry color ${ }^{\mathrm{c}}$} \\
\hline & Total & U.S. No. 1 & & & $>341 \mathrm{~g}$ & $170-341 \mathrm{~g}$ & $114-169 \mathrm{~g}$ & $<114 \mathrm{~g}$ & Cull & $4.4^{\circ} \mathrm{C}$ & $7.2{ }^{\circ} \mathrm{C}$ \\
\hline Mountain Gem Russet & 64.5 & 52.0 & 80 & 1.083 & 33 & 18 & 21 & 13 & 8 & 3.2 & 0.8 \\
\hline Ranger Russet & 57.7 & 40.7 & 71 & 1.087 & 30 & 19 & 19 & 11 & 11 & 3.3 & 0.6 \\
\hline Russet Burbank & 49.8 & 26.9 & 54 & 1.076 & 21 & 19 & 13 & 16 & 18 & 3.8 & 1.0 \\
\hline Russet Norkotah & 38.2 & 29.4 & 77 & 1.073 & 14 & 24 & 21 & 24 & 10 & 3.7 & 1.0 \\
\hline Significance & $* * *$ & $* * *$ & $* * *$ & $* * *$ & $* * *$ & $*$ & $*$ & $* * *$ & $* * *$ & $* *$ & $* *$ \\
\hline $\mathrm{LSD}_{0.05}$ & 3.6 & 4.0 & 5 & 0.002 & 6 & 5 & 6 & 3 & 4 & 0.3 & 0.2 \\
\hline
\end{tabular}

$n s$ Not significant

${ }^{\text {a }}$ Trials were conducted from 2012 to 2014

${ }^{\mathrm{b}}$ Specific gravities were determined using the weight-in-air, weight-in-water method

${ }^{\mathrm{c}}$ French fry scores rated using USDA standards, with $0=$ light and $4=$ dark. A rating of $\leq 2.0$ is an acceptable score. Tubers were evaluated following $3-$

4 months storage at 4.4 or $7.2^{\circ} \mathrm{C}$

* Significant at $p=0.05$

** Significant at $p=0.01$

$* * *$ Significant at $p=<0.0001$ 
Table 2 Total yield, U.S. No. 1 yield, percent No. 1's, and tuber specific gravity of Mountain Gem Russet, Ranger Russet, and Russet Norkotah in early-season irrigated trials grown in Idaho, Oregon, and Washington, 2011 to $2014^{\mathrm{a}}$

\begin{tabular}{lllll}
\hline & ID & OR & WA & Mean \\
\hline Total yield (mt/ha) & & & & \\
$\quad$ Mountain Gem Russet & 60 & 69 & 56 & 61.7 \\
$\quad$ Ranger Russet & 50 & 60 & 52 & 53.9 \\
$\quad$ Russet Norkotah & 57 & 39 & 46 & 47.5 \\
U.S. No. 1 yield (mt/ha) & & & & \\
Mountain Gem Russet & 54 & 60 & 46 & 53.0 \\
Ranger Russet & 42 & 50 & 42 & 44.7 \\
$\quad$ Russet Norkotah & 52 & 31 & 35 & 39.1 \\
\% U.S. No. 1 & & & & \\
$\quad$ Mountain Gem Russet & 89 & 86 & 81 & 85.6 \\
$\quad$ Ranger Russet & 84 & 84 & 81 & 82.8 \\
Russet Norkotah & 90 & 78 & 76 & 81.2 \\
Specific gravity & & & & \\
$\quad$ Mountain Gem Russet & 1.081 & 1.072 & 1.073 & 1.075 \\
$\quad$ Ranger Russet & 1.085 & 1.076 & 1.077 & 1.080 \\
$\quad$ Russet Norkotah & 1.076 & 1.067 & 1.074 & 1.072 \\
\hline
\end{tabular}

${ }^{a}$ Trial locations were Parma, (ID), Hermiston, (OR), and Othello (WA). ID, OR, and WA means represent 2012 to 2014 Early Western Regional Potato Variety Trials

\section{Tuber Quality Characteristics and Usage}

\section{Processing Characteristics}

Fry color scores for Mountain Gem Russet tubers, harvested from full-season trials in ID and OR and stored for extended periods at 6.7 to $7.2{ }^{\circ} \mathrm{C}$, were consistently acceptable $(\leq 2.0$, USDA scale; $0=$ light, $4=$ dark), with the exception of the Hermiston, OR site where the scores for all three cultivars exceeded 2.0 (Tables 1, 3 and 4). Averaged across these sites, fry color for Mountain Gem Russet was similar to Ranger Russet but lighter than Russet Burbank. When stored at $4.4{ }^{\circ} \mathrm{C}$, Mountain Gem Russet tubers produced unacceptably dark fries with fry scores similar to Ranger Russet but slightly lighter than Russet Burbank (Table 1). Based on these data, low temperature sweetening for Mountain Gem Russet appears to be comparable to Ranger Russet and slightly less than Russet Burbank.

Mountain Gem Russet fry color was consistently acceptable in comprehensive processing evaluations after 7 months of storage $\left(3\right.$ months at $8.9^{\circ} \mathrm{C}$ followed by 4 months at $6.7^{\circ} \mathrm{C}$ ) using tubers obtained from trials in Idaho, Oregon and Washington (Table 5). Fry color uniformity, which is an important factor in evaluating processing quality, was characterized by determining the difference in reflectance between the stem and bud ends of tubers obtained from Idaho, Oregon and Washington. Mountain Gem Russet consistently had the
Table 3 Total yield, U.S. No. 1 yield, percent No. 1's, and tuber specific gravity of Mountain Gem Russet, Ranger Russet, and Russet Burbank in full-season irrigated trials grown in Idaho, Oregon, and Washington, 2011 to $2014^{\mathrm{a}}$

\begin{tabular}{lllll}
\hline & ID & OR & WA & Mean \\
\hline Total yield (mt/ha) & & & & \\
$\quad$ Mountain Gem Russet & 70 & 90 & 96 & 85.3 \\
Ranger Russet & 65 & 81 & 88 & 78.0 \\
Russet Burbank & 60 & 91 & 81 & 77.3 \\
U.S. No. 1 yield (mt/ha) & & & & \\
Mountain Gem Russet & 59 & 76 & 84 & 73.0 \\
Ranger Russet & 50 & 65 & 69 & 61.3 \\
Russet Burbank & 36 & 67 & 57 & 53.5 \\
\% U.S. No. 1 & & & & \\
Mountain Gem Russet & 84 & 84 & 87 & 85.0 \\
Ranger Russet & 77 & 81 & 79 & 79.0 \\
Russet Burbank & 60 & 73 & 70 & 67.7 \\
Specific gravity & & & & \\
Mountain Gem Russet & 1.080 & 1.074 & 1.077 & 1.077 \\
Ranger Russet & 1.086 & 1.075 & 1.082 & 1.081 \\
Russet Burbank & 1.076 & 1.072 & 1.075 & 1.075 \\
Fry color from 7.2 ${ }^{\circ} \mathrm{C}^{\mathrm{b}}$ & & & & \\
Mountain Gem Russet & 0.8 & 2.2 & 1.0 & 1.3 \\
Ranger Russet & 0.6 & 2.4 & 1.0 & 1.3 \\
Russet Burbank & 0.9 & 2.6 & 2.0 & 1.8 \\
\hline
\end{tabular}

${ }^{a}$ Trial locations were Aberdeen and Kimberly (ID), Hermiston,(OR), and Othello (WA). Means represent combined data from 2011 Tri-State Potato Variety Trials, and 2012 to 2014 Western Regional Potato Variety Trials

${ }^{\mathrm{b}}$ French fry scores rated using USDA standards, with $0=$ light and $4=$ dark. A rating of $\leq 2.0$ is an acceptable score. Tubers were evaluated following 6-11 weeks storage at $7.2 \mathrm{C}\left(6.7^{\circ} \mathrm{C}\right.$ for WA $)$

highest fry color uniformity in all three states, determined as the smallest difference in reflectance values between the stem and bud ends. Percent reducing sugars in the stem end of Mountain Gem Russet tubers was consistently lower than Ranger Russet and Russet Burbank in all three states, but was similar to Ranger Russet and Russet Burbank in the bud end.

Percentage of tubers sprouting after 7 months in storage for Mountain Gem Russet was similar to or slightly less than Ranger Russet, but substantially higher than Russet Burbank (Table 5). Length of sprouts for Mountain Gem Russet tubers after 7 months of storage was similar to or greater than Ranger Russet and much greater than Russet Burbank. These data indicate that Mountain Gem Russet has a much shorter dormant period than Russet Burbank and a slightly shorter dormancy period than Ranger Russet. Based on storage trials conducted at Kimberly, Idaho dormancy length of Mountain Gem Russet is about 70 days shorter than Russet Burbank.

Mean ratings for post-harvest processing and culinary characteristics for Mountain Gem Russet, Ranger Russet and 
Table 4 Total yield, U.S. No. 1 yield, percent U.S. No. 1, specific gravity, and fry color of Mountain Gem Russet, Ranger Russet and Russet Burbank in full-season irrigated field studies conducted as part of the 2012-2014 Western Regional Potato Variety Trials ${ }^{\mathrm{a}}$

\begin{tabular}{|c|c|c|c|c|c|c|c|c|}
\hline & \multirow[t]{2}{*}{$\mathrm{CA}$} & \multirow[t]{2}{*}{$\mathrm{CO}$} & \multicolumn{3}{|l|}{ ID } & \multirow[t]{2}{*}{ OR } & \multirow[t]{2}{*}{ WA } & \multirow[t]{2}{*}{ Mean } \\
\hline & & & 1 & 2 & 3 & & & \\
\hline \multicolumn{9}{|l|}{ Total yield (mt/ha) } \\
\hline Mountain Gem Russet & 53.0 & 52.5 & 58.7 & 70.4 & 83.3 & 89.8 & 94.5 & 71.7 \\
\hline Ranger Russet & 50.9 & 45.8 & 49.7 & 65.6 & 78.3 & 81.0 & 87.9 & 65.6 \\
\hline Russet Burbank & 44.2 & 42.3 & 44.2 & 55.5 & 81.6 & 91.4 & 81.3 & 62.9 \\
\hline \multicolumn{9}{|l|}{ U.S No.1 yield (mt/ha) } \\
\hline Mountain Gem Russet & 45.5 & 46.5 & 48.2 & 55.8 & 74.9 & 79.1 & 80.5 & 61.5 \\
\hline Ranger Russet & 39.9 & 39.4 & 36.7 & 44.7 & 69.7 & 65.5 & 69.0 & 52.1 \\
\hline Russet Burbank & 33.0 & 29.5 & 22.9 & 30.9 & 58.0 & 65.6 & 56.7 & 42.4 \\
\hline \multicolumn{9}{|l|}{ \% U.S. No. 1} \\
\hline Mountain Gem Russet & 86 & 89 & 82 & 79 & 90 & 87 & 85 & 85.4 \\
\hline Ranger Russet & 78 & 86 & 74 & 68 & 89 & 81 & 79 & 79.1 \\
\hline Russet Burbank & 74 & 69 & 53 & 56 & 71 & 73 & 70 & 66.6 \\
\hline \multicolumn{9}{|l|}{ Specific gravity } \\
\hline Mountain Gem Russet & 1.087 & 1.084 & 1.084 & 1.081 & 1.077 & 1.071 & 1.075 & 1.080 \\
\hline Ranger Russet & 1.096 & 1.091 & 1.089 & 1.085 & 1.085 & 1.075 & 1.082 & 1.086 \\
\hline Russet Burbank & 1.089 & 1.084 & 1.075 & 1.076 & 1.078 & 1.072 & 1.075 & 1.079 \\
\hline \multicolumn{9}{|l|}{ Fry color ${ }^{b}$} \\
\hline Mountain Gem Russet & n.a. & 1.7 & 0.9 & 0.8 & n.a. & 1.2 & 1.3 & 1.2 \\
\hline Ranger Russet & n.a. & 2.3 & 0.8 & 0.5 & n.a. & 1.3 & 1.7 & 1.3 \\
\hline Russet Burbank & n.a. & 2.3 & 1.2 & 0.8 & n.a. & 1.8 & 2.7 & 1.8 \\
\hline
\end{tabular}

${ }^{\mathrm{a}}$ Trial locations were Tulelake (CA), San Luis Valley (CO), Aberdeen (ID-1), Kimberly (ID-2), Parma (ID-3), Hermiston (OR-1), and Othello (WA)

${ }^{\mathrm{b}}$ French fry scores rated using USDA standards, with $0=$ light and $4=$ dark. A rating of $\leq 2.0$ is an acceptable score. Tubers were evaluated following 6-11 weeks storage at $7.2 \mathrm{C}$, with the exception of WA with storage at $6.7^{\circ} \mathrm{C}$
Russet Burbank were compiled over a 3-year period using data from tubers obtained from the aforementioned Washington, Idaho and Oregon trials (Table 6). The rating values combine the individual scores for fry color characteristics from the field prior to storage and after 60 days of storage at 8.9 and $6.7^{\circ} \mathrm{C}(0-5$ scale $)$, reducing sugar concentrations after 60 days storage at 8.9 or $6.7^{\circ} \mathrm{C}(1-5$ scale $)$, tuber specific gravity ( $0-5$ scale) and average taste panel sensory evaluations ( $1-5$ scale) for tubers grown at the three locations. Mountain Gem Russet post-harvest processing and culinary ratings were consistently higher than Russet Burbank at all locations and were similar to Ranger Russet for the Idaho and Oregon trials, but lower in the Washington trials. Averaged over the 3-year period and across production sites, the mean post-harvest rating for Mountain Gem Russet was higher than Russet Burbank but slightly lower than Ranger Russet, indicating good early processing potential out of short-term storage.

In 3 years (2012-14) of Western Regional Trials conducted in WA, ID and OR, Mountain Gem Russet tubers produced highly acceptable USDA 0 fries that were 8 and $21 \%$ lighter in color $(P<0.05)$ than fries from Ranger Russet and Russet
Burbank tubers, respectively, directly following harvest (data not shown). Moreover, in contrast to Mountain Gem Russet, at-harvest uniformity of fry color was unacceptable for Russet Burbank and Ranger Russet from most sites in all years. Fry color is considered non-uniform and unacceptable when the difference between stem and bud photovolt values equals or exceeds nine photovolt reflectance units. Hence, the processing quality of Mountain Gem Russet tubers directly following harvest was superior to Ranger and Russet Burbank tubers.

\section{Fresh Characteristics}

Fresh merit ratings were determined for Mountain Gem Russet, Ranger Russet, Russet Burbank, and Russet Norkotah using tubers harvested from seven locations included in the Western Regional Potato Variety Trials during 2012-2014 (Table 7). The merit scores represent a preference rating based on overall tuber appearance, uniformity of size and shape, and yield. Mountain Gem Russet fresh merit scores were relatively high at five of the seven trial locations and had the highest average score across all locations. 
Table 5 Post-harvest processing characteristics of Mountain Gem Russet, Ranger Russet, and Russet Burbank following 7 months of storage at $95 \%$ humidity $\left(3\right.$ months at $8.9{ }^{\circ} \mathrm{C}$ and 4 months at $\left.6.7^{\circ} \mathrm{C}\right)$.
All post-harvest evaluations and ratings were conducted at Pullman, WA in 2011-2014 using tubers from trials at Aberdeen, ID, Hermiston, OR, and Othello, WA

\begin{tabular}{|c|c|c|c|c|c|c|c|c|c|c|}
\hline \multirow[t]{2}{*}{ Clone } & \multicolumn{3}{|c|}{ Photovolt reading $^{\mathrm{a}}$} & \multirow{2}{*}{$\begin{array}{l}\text { Difference }^{\mathrm{b}} \\
\text { Stem vs bud }\end{array}$} & \multirow{2}{*}{$\begin{array}{l}\text { USDA color } \\
\text { Rating }^{\mathrm{c}}\end{array}$} & \multicolumn{3}{|c|}{$\%$ Reducing sugars $^{\mathrm{d}}$} & \multicolumn{2}{|l|}{ Sprouting } \\
\hline & Stem & Bud & Avg. & & & Stem & Bud & Avg. & $\%$ of tubers & Sprout length (mm) \\
\hline \multicolumn{11}{|l|}{ Washington } \\
\hline Mountain Gem R. & 38.1 & 41.2 & $39.7 b$ & $8.3 \mathrm{a}^{\mathrm{e}}$ & 0.0 & 0.87 & 0.72 & 0.79 & $93 b$ & 23 \\
\hline Ranger Russet & 27.4 & 39.2 & $33.3 \mathrm{a}$ & $12.7 \mathrm{~b}$ & 1.0 & 1.67 & 0.77 & 1.22 & $93 b$ & 16 \\
\hline Russet Burbank & 25.7 & 41.7 & $33.7 \mathrm{a}$ & $16.1 \mathrm{~b}$ & 1.3 & 1.88 & 0.69 & 1.28 & $7 \mathrm{a}$ & 1 \\
\hline \multicolumn{11}{|l|}{ Idaho } \\
\hline Mountain Gem R. & 37.8 & 37.9 & $37.8 b$ & $7.7 \mathrm{a}$ & 0.0 & 0.84 & 0.84 & 0.84 & $47 b$ & 6 \\
\hline Ranger Russet & 28.4 & 39.4 & $33.9 \mathrm{a}$ & $11.2 \mathrm{a}$ & 1.0 & 1.55 & 0.76 & 1.16 & $65 c$ & 7 \\
\hline Russet Burbank & 24.4 & 42.1 & $33.2 \mathrm{a}$ & $18.7 \mathrm{~b}$ & 1.7 & 2.05 & 0.68 & 1.37 & $0 \mathrm{a}$ & 0 \\
\hline \multicolumn{11}{|l|}{ Oregon } \\
\hline Mountain Gem R. & 34.6 & 38.5 & $36.6 b$ & $6.1 \mathrm{a}$ & 0.3 & 1.07 & 0.85 & 0.96 & $88 b$ & 27 \\
\hline Ranger Russet & 26.0 & 39.7 & $32.8 \mathrm{a}$ & $13.7 \mathrm{~b}$ & 1.3 & 1.83 & 0.75 & 1.29 & $88 b$ & 18 \\
\hline Russet Burbank & 22.1 & 41.2 & $31.7 \mathrm{a}$ & $19.2 \mathrm{c}$ & 2.0 & 2.37 & 0.68 & 1.53 & $3 a$ & 1 \\
\hline
\end{tabular}

${ }^{a}$ Fries $(3 / 8 " \times 11 / 8$ ") were fried at $191 \mathrm{C}$ for $3.5 \mathrm{~min}$ and color was measured with a Photovolt reflectance meter within 3 min of removal from oil. A photovolt reading of $\leq 19$ is considered unacceptably dark (see note 3 below)

${ }^{b}$ An absolute difference of $\geq 9$ photovolt units between bud and stem end constitutes non-uniform fry color. Values represent the averages of actual photovolt differences of the replicate tubers in each of 3 years and are not computed directly from the averaged stem and bud values listed in the table

${ }^{\mathrm{c}}$ USDA color $(0=$ light and $4=$ dark $)$ ratings were assigned based upon photovolt reflectance readings of the darkest ends of fries (typically stem ends); Photovolt readings $\geq 31=$ USDA $0,25-30=$ USDA $1,20-24=$ USDA 2, 15-19=USDA 3, $\leq 14=$ USDA 4. Data are averaged over years

${ }^{\mathrm{d}}$ Dry matter basis

${ }^{\mathrm{e}}$ Letters indicate $\operatorname{LSD}(P<0.05)$

\section{Sensory Evaluations}

Six taste panel evaluations of baked potatoes were conducted over a 3 year period (2 per year) comparing sensory attributes of Mountain Gem Russet, Russet Burbank and Russet Norkotah. Ratings were based on a 1-9 scale with one representing 'extremely dislike' and nine representing 'extremely like' with panel evaluation protocols described in Table 8. Mountain Gem Russet performed very well in early storage evaluations conducted 2 months after harvest receiving ratings for all five sensory attributes that were similar to Russet Burbank. Sensory ratings for aroma, texture and after taste were similar to Russet Norkotah, but were higher than Russet Norkotah for flavor and overall acceptance. In late storage evaluations it received ratings that were similar to Russet Burbank and Russet Norkotah for all attributes.

\section{Specific Gravity}

Mean specific gravity for Mountain Gem Russet in the aforementioned trials was generally higher than Russet Norkotah, lower than Ranger Russet and similar to slightly higher than Russet Burbank (Tables 1, 2, 3, and 4).

\section{Tuber Defects}

Mountain Gem Russet's resistance to growth cracks in the Western Regional Trials was similar to Ranger Russet, greater than Russet Burbank but lower than Russet Norkotah (Table 9). Its resistance to second growth was similar to Russet Norkotah and greater than Ranger Russet and Russet Burbank. It did show susceptibility to shatter bruise, being similar Russet Burbank, and slightly more susceptible than Ranger Russet and Russet Norkotah. Its resistance to blackspot bruise was greater than Ranger Russet and Russet Norkotah and similar to Russet Burbank. In these trials, the incidence of hollow heart was relatively low, similar to Russet Burbank but slightly higher than Ranger Russet and Russet Norkotah. Tuber shrinkage during 9 months of storage was slightly higher than Russet Burbank.

\section{Disease and Pest Responses}

Methodology: Evaluations of disease responses for Mountain Gem Russet were based on data collected from replicated field trials conducted for a minimum of 2 years. Disease response ratings were assigned to Mountain Gem Russet, based on the multiple years of data. Ratings for disease responses are used in place of quantitative data to allow for more direct 
Table 6 Mean ratings for post-harvest processing and culinary characteristics $^{\mathrm{a}}$ of Mountain Gem Russet, Ranger Russet, and Russet Burbank in full-season studies included in the 2012-2014 Western Regional Potato Variety Trials. Post-harvest evaluations and ratings were conducted at Pullman, WA using tubers from trials at Aberdeen, ID, Hermiston, OR, and Othello, WA

\begin{tabular}{lllll}
\hline & Washington & Idaho & Oregon & 3 state mean \\
\hline Mountain Gem Russet & 20.2 & 26.1 & 26.1 & 24.1 \\
Ranger Russet & 24.4 & 26.7 & 27.7 & 26.1 \\
Russet Burbank & 14.6 & 12.7 & 13.5 & 13.6 \\
\hline
\end{tabular}

${ }^{a}$ Values were assigned based on the sum of individual ratings for fry color from the field, after storage at 8.9 and $6.7 \mathrm{C}$ ( 60 days) $(0-5$ scale), reducing sugar concentrations following 60 days storage at 8.9 and $6.7 \mathrm{C} \mathrm{(1-5}$ scale), specific gravity ( $0-5$ scale), and average sensory evaluations by taste panels (1-5 scale). Maximum value possible was 38 ; higher values are indicative of superior post-harvest attributes

comparisons of Mountain Gem Russet in relation to the standard cultivars used by industry.

Verticillium wilt (Verticillium dahlia) evaluations were conducted at Aberdeen, Idaho using naturally occurring inocula and protocols described by Corsini et al. (1988). Common scab (Streptomyces scabies) was evaluated on tubers collected from three replicates from field trials arranged in a randomized complete block (RCB) using naturally occurring inocula at Aberdeen, Idaho. Mountain Gem Russet also was evaluated in the national common scab trial in 2012-2013 and in 20122014 for common scab response at Aberdeen, Idaho, Becker, Minnesota and Rock Springs, Pennsylvania as described by Haynes et al. (2010). Early blight (Alternaria solani) foliar evaluations were conducted at Aberdeen, Idaho and were based on visual estimates of the amount of leaf area infected in three replicate plots of a RCB design. Tuber evaluations for early blight were conducted using tubers harvested from

Table 7 Fresh Merit Ratings ${ }^{\mathrm{a}}$ for Mountain Gem Russet, Ranger Russet, and Russet Burbank in full-season irrigated field studies conducted as part of the 2012 to 2014 Western Regional Potato Variety Trials $^{\mathrm{b}}$

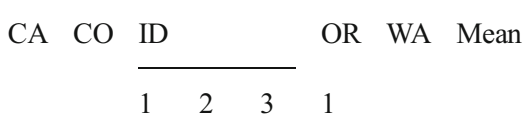

$\begin{array}{lllllllll}\text { Fresh Merit Rating }(1-5,5=\text { best }) & & & & & & \\ \text { Mountain Gem Russet } & 3.8 & 4.7 & 3.8 & 3.1 & 2.8 & 3.0 & 2.5 & 3.4 \\ \text { Ranger Russet } & 3.1 & 4.7 & 2.9 & 2.5 & 2.2 & 2.0 & 1.3 & 2.7 \\ \text { Russet Burbank } & 3.3 & 3.0 & 2.1 & 2.3 & 1.7 & 2.0 & 1.0 & 2.2 \\ \text { Russet Norkotah } & 3.9 & 1.3 & 3.3 & 3.4 & 4.0 & 3.8 & 1.9 & 3.1\end{array}$

${ }^{\text {a }}$ Fresh Merit Rating scale $(1-5$, with $5=$ Best) a preference rating based on overall appearance, yield, and uniformity

b Trial locations were Tulelake (CA), San Luis Valley (CO), Aberdeen (ID-1), Kimberly (ID-2), Parma (ID-3), Hermiston (OR-1), and Othello (WA) plants used in assessing foliar resistance, following 3.5 months of storage at $10^{\circ} \mathrm{C}$.

To enhance the conditions for early blight tuber lesions, vines were removed by flailing while still green and tubers were harvested 2 weeks after vine removal. Before tubers were placed in storage, each sample was tumbled for $30 \mathrm{~s}$ in a cement mixer lined with rough carpet to abrade and provide small wounds as entry points for Alternaria spores. Evaluations for soft rot were done on tubers washed at harvest and stored for approximately 3 months at $10^{\circ} \mathrm{C}$. These tubers from storage were then tumbled for $30 \mathrm{~s}$ in a carpet-lined cement mixer. Tubers were then dipped for $5 \mathrm{~min}$ in a $5 \times 10^{4}$ cells $/ \mathrm{ml}$ solution of Pectobacterium atrosepticum and then placed in a mist chamber with $100 \% \mathrm{RH}$ at $18{ }^{\circ} \mathrm{C}$. When tubers were sufficiently rotted $(\sim 1$ week) they were removed and scored on a 1-5 scale with five being at least $50 \%$ rot.

Bacterial ring rot evaluations were done in Center, Colorado in 2013 and in Kimberly, Idaho in 2015 using a pathogenic rifampicin-resistant strain (CIC31) of Clavibacter michiganensis subsp. sepedonicus. Freshly cut seed pieces were dipped in a bacterial solution and placed in paper sacks overnight. Seed pieces were planted the next day in a RCB design with 7 inoculated seed pieces planted next to 7 noninoculated seed pieces for control plots.

Late blight (Phytophthorainfestans) field evaluations were conducted at Corvallis, Oregon as described by Mosley et al. (2003) and in the National Late Blight Germplasm Evaluation Trials as described by Haynes et al. (2002).

Evaluations of Potato leafroll virus (PLRV), Potato virus $Y$ (PVY), and Potato virus $X(\mathrm{PVX})$ resistances were conducted at Kimberly, Idaho using virus-infected spreader rows as described by Corsini et al. (1994). Characterization of PVY symptoms caused by different strains $(\mathrm{O}, \mathrm{N}: \mathrm{O}, \mathrm{NTN})$ were done in a greenhouse with foliar symptoms recorded on a weekly basis and any tuber symptoms noted at harvest. Corky ringspot (tobacco rattle virus) evaluations were conducted in the Columbia Basin of Washington using protocols described by Brown et al. (2000).

Storage disease evaluations were performed as described by Corsini and Pavek (1986) with evaluations for dry rot resistance also being conducted at the University of Idaho, Kimberly Research and Extension Center. Tubers were first bruised and then inoculated with a 50/50 mix of Thiabendazole resistant: susceptible strains of Fusarium sambucinum. Following inoculation, potatoes were cured at 12.8 and $95 \%$ relative humidity for 2 weeks, decreased $0.28{ }^{\circ} \mathrm{C} /$ day, and then stored at $7.2^{\circ} \mathrm{F}$. After approximately 3 months in storage, tubers were evaluated for the percentage of dry rot decay and the incidence of the disease, expressed as the percentage of tubers evaluated having more than $5 \%$ decay. Dry rot evaluations were also done at Aberdeen using tubers collected from replicated field plots. Cultures of field-collected isolates of $F$. sambucinum and $F$. solani var. coeruleum were 
Table 8 Sensory evaluations of baked tubers of Mountain Gem Russet, Russet Burbank, and Russet Norkotah, 2011-13

\begin{tabular}{|c|c|c|c|c|c|c|}
\hline \multirow[b]{2}{*}{ Cultivar } & \multicolumn{6}{|c|}{ Early-storage $^{a}$} \\
\hline & Aroma & Flavor $^{\mathrm{c}}$ & Texture & Aftertaste & Acceptance & Average \\
\hline Mountain Gem R. & $6.1 \mathrm{a}$ & $6.3 \mathrm{a}$ & $6.7 \mathrm{a}$ & $5.8 \mathrm{a}$ & $6.3 \mathrm{a}$ & $6.2 \mathrm{a}$ \\
\hline R. Burbank & $5.9 \mathrm{a}$ & $6.0 \mathrm{ab}$ & $6.6 \mathrm{a}$ & $5.7 \mathrm{a}$ & $6.0 \mathrm{ab}$ & $6.1 \mathrm{ab}$ \\
\hline \multirow[t]{2}{*}{ R. Norkotah } & $5.7 \mathrm{a}$ & $5.7 \mathrm{~b}$ & $6.5 \mathrm{a}$ & $5.5 \mathrm{a}$ & $5.8 \mathrm{~b}$ & $5.8 \mathrm{~b}$ \\
\hline & \multicolumn{6}{|c|}{ Late-storage $^{\mathrm{b}}$} \\
\hline Cultivar & Aroma & Flavor & Texture & Aftertaste & Acceptance & Average \\
\hline Mountain Gem R. & $6.1 \mathrm{ab}$ & $6.0 \mathrm{a}$ & $6.5 \mathrm{a}$ & $5.5 \mathrm{a}$ & $5.9 \mathrm{a}$ & $6.0 \mathrm{a}$ \\
\hline R. Burbank & $6.3 \mathrm{a}$ & $6.0 \mathrm{a}$ & $6.1 \mathrm{a}$ & $5.7 \mathrm{a}$ & $5.9 \mathrm{a}$ & $6.0 \mathrm{a}$ \\
\hline R. Norkotah & $5.8 \mathrm{~b}$ & $5.9 \mathrm{a}$ & $6.5 \mathrm{a}$ & $5.5 \mathrm{a}$ & $6.0 \mathrm{a}$ & $5.9 \mathrm{a}$ \\
\hline
\end{tabular}

Blind sensory evaluations were conducted in Pullman, Washington during the 3 year period of 2011-13 (2 sessions/year) using 100 untrained panelists under the supervision of the WSU Food Sensory Laboratory. Panelists were asked to evaluate each sensory attribute for each cultivar on a 1-9 scale with one representing 'extremely dislike' and nine representing 'extremely like'. Tubers were baked at $204{ }^{\circ} \mathrm{C}$ for $1 \mathrm{~h}$, and allowed to cool to room temperature prior to evaluation

${ }^{a}$ Early storage evaluations were conducted approximately 2 months after harvest. The early-harvest tubers were held at a temperature of $9{ }^{\circ} \mathrm{C}$ from harvest until evaluation

${ }^{\mathrm{b}}$ Late storage evaluations were conducted following approximately 6 months of storage at $6.6{ }^{\circ} \mathrm{C}$

${ }^{\mathrm{c}}$ Means in a column followed by different letters indicate least significant difference (LSD), $P<0.05$

used to infect washed tubers. The tubers were inoculated by dipping a "wounding" tool with a set number of pins into solution with a concentration of $1.7 \times 105$ conidia $/ \mathrm{ml}$. This tool is then used to produce entry wounds in one end of the tuber with $F$. sambucinum and the other end is wounded with a tool carrying F.s.var. coeruleum. Before and after inoculation, the tubers were kept in $10^{\circ} \mathrm{C}$ storage. Approximately 4 months post inoculation, tubers were visually scored for dry rot using a $0-5$ scale with five indicating high dry rot present.

Disease and Pest Response: Mountain Gem Russet is notable for its resistances to common scab and tuber late blight and moderate resistance to soft rot (Table 10). It displays moderate susceptibility to Verticillium wilt, net necrosis and corky ringspot, and susceptibility to foliar and tuber early blight, foliar late blight, PVX, PVY, and PLRV.

Mountain Gem Russet's susceptibility to most diseases is similar to Russet Burbank, except it has greater resistance to tuber late blight (Table 10). Compared to Russet Norkotah, it also has greater resistance to tuber late blight but greater susceptibility to dry rot.

Mountain Gem Russet is very susceptible to PVY, having been tested in the field and greenhouse against multiple isolates of three strains (NTN, N:O, O). Observations of visual symptoms of PVY infected plants in the field and greenhouse show that it expresses typical to severe mosaic symptoms when infected with different strains of PVY. Under conditions conducive to necrotic tuber symptom development, no tuber necrosis was noted for any of the PVY strains tested (Table 11).

Mountain Gem Russet exhibits typical foliar symptoms of bacterial ring rot at Center, Colorado, a short growing season area, with at least $50 \%$ of the plants showing symptoms at 91 days after planting compared to Russet Burbank which showed symptoms at 82 days. At Kimberly, Idaho, which has a longer growing season than Center, Colorado, foliar

Table 9 Evaluation of internal and external defects of Mountain Gem Russet, Ranger Russet, Russet Burbank, and Russet Norkotah in Idaho, Oregon, and Washington in full season irrigated Western Regional Potato Variety Trials from 2011 to 2014

\begin{tabular}{lllllll}
\hline Cultivar & Growth cracks & Second growth & Shatter bruise & Hollow heart & Blackspot bruise $^{\mathrm{a}, \mathrm{d}}$, & Tuber Shrinkage $^{\mathrm{e}}$ \\
\hline Mountain Gem Russet & 3.9 & 4.3 & 2.7 & 5.7 & 2.6 & 10 \\
Ranger Russet & 4.0 & 3.9 & 3.0 & 1.0 & 1.7 & - \\
Russet Burbank & 3.5 & 3.4 & 2.5 & 5.8 & 2.5 & 8 \\
Russet Norkotah & 4.5 & 4.5 & 3.1 & 3.2 & 2.3 & - \\
\hline
\end{tabular}

${ }^{\text {a }}$ Rated using a $1-5$ scale with $1=$ severe and $5=$ none observed

${ }^{\mathrm{b}}$ Rated as the percentage of tubers $>341 \mathrm{~g}$ with hollow heart and brown center

c Average of 21 trials

${ }^{\mathrm{d}}$ Average of 6 trials grown at Aberdeen and Kimberly, Idaho, mechanically bruised and allowed for bruise development then evaluated

${ }^{\mathrm{e}}$ Value is percent weight loss during 9 months of storage in months of storage in (2013-2014). Value reflects an average across three storage temperatures of $5.6,7.2$ and $8.9^{\circ} \mathrm{C}$ at $95 \%$ humidity 
Table 10 Disease response of Mountain Gem Russet relative to Ranger Russet, Russet Burbank, and Russet Norkotah ${ }^{\mathrm{a}}$

\begin{tabular}{|c|c|c|c|c|c|c|c|c|c|c|c|c|c|}
\hline \multirow[t]{2}{*}{ Cultivar } & \multirow[t]{2}{*}{ Vert. wilt } & \multirow[t]{2}{*}{ Common scab } & \multicolumn{2}{|c|}{ Early blight } & \multicolumn{2}{|c|}{ Late blight } & \multicolumn{3}{|c|}{ Viruses $^{\mathrm{b}}$} & \multicolumn{2}{|c|}{ Symptoms of virus infection } & \multicolumn{2}{|c|}{ Storage diseases } \\
\hline & & & Foliar & Tuber & Foliar & Tuber & PLRV & $\mathrm{PVY}^{\mathrm{O}}$ & PVX & Net Nec. & Corky ringspot & Soft rot & Dry rot \\
\hline Mountain Gem & MS & $\mathrm{R}$ & $\mathrm{S}$ & $\mathrm{S}$ & $\mathrm{S}$ & $\mathrm{R}$ & VS & VS & VS & MS & MS & MR & $\mathrm{S} / \mathrm{MR}^{\mathrm{c}}$ \\
\hline Ranger $\mathrm{R}$ & MR & $\mathrm{S}$ & MS & MS & $\mathrm{S}$ & VS & $\mathrm{S}$ & $\mathrm{S}$ & MR & MS & $\mathrm{S}$ & MR & MS \\
\hline R Burbank & $\mathrm{S}$ & $\mathrm{R}$ & MS & MS & $\mathrm{S}$ & $\mathrm{S}$ & $\mathrm{S}$ & $\mathrm{S}$ & VS & $\mathrm{S}$ & $\mathrm{S}$ & MS & $\mathrm{S} / \mathrm{MS}^{\mathrm{c}}$ \\
\hline R Norkotah & $\mathrm{S}$ & MR & $\mathrm{S}$ & $\mathrm{S}$ & $\mathrm{S}$ & VS & $\mathrm{S}$ & VS & VS & MR & $\mathrm{S}$ & MS & MR \\
\hline
\end{tabular}

${ }^{a}$ Responses of Mountain Gem Russet to diseases were based on a minimum of 2 years of controlled field evaluations. Responses were defined as very resistant (VR), resistant (R), moderately resistant (MR), moderately susceptible (MS), susceptible (S), and very susceptible (VS). Disease evaluations were conducted at the following locations: Verticillium wilt - Aberdeen, ID and Hermiston, OR; Corky ringspot - Prosser, WA; Common scab Aberdeen, ID; Early blight, Pectobacterium (syn. Erwinia) soft rot, Fusarium dry rot - Aberdeen, ID; Powdery scab of Tuber - Viruses and PLRV net necrosis - Kimberly, ID; Late blight - Corvallis, OR

${ }^{\mathrm{b}}$ Virus responses are based on seed borne infections as determined by ELISA, following field infection with PLRV from aphid vectored source of interplanted virus infected potato, mechanical inoculation and aphid vectored PVY, and mechanical inoculation with PVX

${ }^{\mathrm{c}} \mathrm{S}$ for Fusarium sambucinum, MR or MS for F. solanivar. coeruleum. Other cultivars showed approximately equal resistance responses for both Fusarium species

symptoms were apparent with first observations at 100 days. Foliar symptoms included interveinal chlorosis and necrosis, leaf margin necrosis, and whole stem green wilt.

In the study conducted at Kimberly, ID over two growing seasons, Mountain Gem Russet and Russet Burbank had similar susceptibility to Fusarium dry rot development in bruised and inoculated tubers. Average severity to dry rot decay for Mountain Gem Russet was $63 \%$ with an average $88 \%$ incidence (tubers with $>5 \%$ severity), compared to $55 \%$ severity and $84 \%$ incidence for Russet Burbank. Results at Aberdeen showed that Mountain Gem Russet was susceptible to $F$. sambucinum with a score of 4.7 and moderately resistant to F.s. var. coeruleum with a score of 1.7 .

\section{Biochemical and Nutritional Characteristics}

Mountain Gem Russet, Ranger Russet, Russet Burbank and Russet Norkotah tubers, grown at Aberdeen, ID, were analyzed 4 weeks after harvest over a 3-year period (20122014) to assess biochemical and nutritional components (Table 12). Dry matter content of Mountain Gem Russet was comparable to Russet Burbank and Russet Norkotah, but significantly less than Ranger Russet. Sucrose content was similar to Russet Burbank, higher than Russet Norkotah but lower than Ranger Russet. Glucose concentration was not significantly different from the other three cultivars. Protein content of Mountain Gem Russet was similar to Ranger Russet but higher than Russet Burbank and Russet Norkotah. Mountain Gem Russet had greater Vitamin C content than Russet Norkotah or Russet Burbank, but lower values than Ranger Russet - a cultivar noted as having high levels of Vitamin C in its tubers (Love et al. 2004). Total glycoalkaloids were lower for Mountain Gem Russet than Ranger Russet and similar to Russet Burbank and Russet Norkotah. All of these cultivars, however, have acceptably low values.

\section{Management}

A number of studies on the management of Mountain Gem Russet have been conducted in southern Idaho and the Columbia Basin. Results of these studies may provide growers in these and other production regions with the basis for developing appropriate management guidelines for their locale.

Table 11 Foliar and tuber symptoms in Potato virus Y (PVY) infected plants of Mountain Gem Russet and Yukon Gold (standard susceptible variety used for PVY tuber symptoms). Foliar and tuber symptoms are from primary infections evaluated in a greenhouse over a 4 to 6 week period in 2015

\begin{tabular}{|c|c|c|c|c|c|c|}
\hline \multirow[t]{2}{*}{ Cultivar } & \multicolumn{3}{|c|}{ Mosaic foliar symptoms: Average/Maximum (other symptoms) ${ }^{1}$} & \multicolumn{3}{|c|}{$\%$ of tubers with PVY tuber necrosis at harvest } \\
\hline & $\mathrm{N}: \mathrm{O}$ & NTN & $\mathrm{O}$ & $\mathrm{N}: \mathrm{O}$ & NTN & $\mathrm{O}$ \\
\hline Mountain Gem Russet & $1.8 / 2$ (none) & $1.8 / 2$ (none) & $2.4 / 3(\mathrm{VN}, \mathrm{RS})$ & 0.0 & 0.0 & 0.0 \\
\hline Yukon Gold & $1.8 / 3(\mathrm{VN})$ & $2.8 / 3(\mathrm{LD}, \mathrm{VN}, \mathrm{NL}, \mathrm{RS})$ & $2.1 / 3(\mathrm{LD}, \mathrm{VN}, \mathrm{NL}, \mathrm{RS})$ & 46.3 & 20.0 & 0.0 \\
\hline
\end{tabular}


Table 12 Biochemical analyses of Mountain Gem Russet, Ranger Russet, Russet Burbank, and Russet Norkotah, tubers from Western Regional Trials (2012-2014) conducted at Aberdeen, ID ${ }^{\mathrm{a}}$

\begin{tabular}{lllllll}
\hline Cultivar & $\begin{array}{l}\text { Dry matter } \\
(\%)\end{array}$ & $\begin{array}{l}\text { Sucrose }^{\mathrm{c}} \\
\left(\% \mathrm{FWB}^{\mathrm{b}}\right)\end{array}$ & $\begin{array}{l}\text { Glucose }^{\mathrm{c}} \\
\left(\% \mathrm{FWB}^{\mathrm{b}}\right)\end{array}$ & $\begin{array}{l}\text { Protein }^{\mathrm{d}} \\
(\% \mathrm{DWB})\end{array}$ & $\begin{array}{l}\text { Vitamin C } \\
(\mathrm{mg} / 100 \mathrm{~g} \mathrm{FWB})\end{array}$ & $\begin{array}{l}\text { Total Glycoalkaloids }^{\mathrm{f}} \\
\left.\mathrm{mg}^{\mathrm{b}} / 100 \mathrm{~g} \mathrm{FWB}^{\mathrm{b}}\right)\end{array}$ \\
\hline Mountain Gem Russet & $20.5 \mathrm{~b}$ & $0.135 \mathrm{~b}$ & 0.068 & $5.73 \mathrm{a}$ & $26.2 \mathrm{~b}$ & $3.06 \mathrm{~b}$ \\
Ranger Russet & $22.7 \mathrm{a}$ & $0.161 \mathrm{a}$ & 0.062 & $5.41 \mathrm{a}$ & $30.8 \mathrm{a}$ & $4.12 \mathrm{a}$ \\
Russet Burbank & $19.7 \mathrm{~b}$ & $0.134 \mathrm{~b}$ & 0.081 & $4.80 \mathrm{~b}$ & $18.9 \mathrm{~d}$ & $3.14 \mathrm{~b}$ \\
Russet Norkotah & $20.3 \mathrm{~b}$ & $0.115 \mathrm{c}$ & 0.083 & $4.57 \mathrm{~b}$ & $21.6 \mathrm{c}$ & $2.83 \mathrm{~b}$ \\
LSD 0.05 & 0.1 & 0.013 & $\mathrm{NS}$ & 0.46 & 1.9 & 0.97 \\
\hline
\end{tabular}

${ }^{\text {a }}$ Analyses were conducted on freeze-dried tuber tissue at Aberdeen, ID; tissue was taken from tubers stored at $8.9^{\circ} \mathrm{C}$ for 4 weeks following their harvest

${ }^{\mathrm{b}}$ FWB Fresh Weight Basis, DWB Dry Weight Basis; Sucrose and glucose values of $0.15 \%$ and $0.10 \%$ respectively are maximum values for acceptable fry color in this evaluation, with glucose being the greater contributor to fry color.

${ }^{\mathrm{c}}$ Sugar concentrations were calculated according to: Glucose and sucrose measurements in potatoes, Application Note No. 102, Scientific Division, Yellow Springs Instrument Co., Yellow Springs, Ohio 45387

${ }^{\mathrm{d}}$ Protein content was determined using a Coomassie blue protein assay developed from the protocol of Bradford (1976)

${ }^{\mathrm{e}}$ Vitamin C (ascorbic acid) content in tubers was determined using a microfluorometric method detailed in the Official Methods of Analysis Handbook, 14th edition, sections 43.069-43.075

${ }^{\mathrm{f}}$ Total glycoalkaloids was determined using the protocol of Bergers (1980)

${ }^{\mathrm{g}}$ Mean values within a column followed by different letters are significantly different $(P<0.05)$ from one another based on Student's t- test. NS equals not significant

\section{Southern Idaho}

Optimal seed size for Mountain Gem Russet is approximately 57 to $85 \mathrm{~g}$. Recommended final planting depth is $20 \mathrm{~cm}$ from the top of the hill to the top of the planted seed piece.

Seed should be treated and planted in soil with optimal temperature $\left(7.2\right.$ to $\left.12.8^{\circ} \mathrm{C}\right)$ to minimize the potential for soft rot decay. Dry rot potential of seed lots should also be determined and seed should be treated with an effective fungicide when needed.

Mountain Gem Russet has exhibited good resistance to metribuzin when applied at labeled rates. It has an erect, medium sized vine that matures late in the growing season but competes reasonably well with weeds after row closure during early to mid-tuber bulking. Soils infested with root-knot nematodes or a history of severe early die problems should be fumigated. Effective fungicide application programs should be used to prevent serious early blight infections.

\section{Early Harvest Production}

For early harvest production, seed piece spacing with rows spaced $91 \mathrm{~cm}$ apart should be 23 to $25 \mathrm{~cm}$ for fresh market use, with seed spacing increased to 25 to $28 \mathrm{~cm}$ for processing.

The total seasonal nitrogen requirements for Mountain Gem Russet are about 10-20 \% less than Russet Burbank (Stark et al. 2004) per unit of yield produced, depending on the length of the growing season. For early harvest production in southern Idaho, total soil plus fertilizer $\mathrm{N}$ recommendations should range from about $180-200 \mathrm{~kg} \mathrm{~N} / \mathrm{ha}$ in areas with a $45 \mathrm{t} /$ ha yield potential, to $220-240 \mathrm{~kg} \mathrm{~N} / \mathrm{ha}$ with a $56 \mathrm{t} / \mathrm{ha}$ yield potential, and $260-280 \mathrm{~kg} \mathrm{~N} / \mathrm{ha}$ in areas with a $67 \mathrm{t} / \mathrm{ha}$ yield potential. About 120 to $160 \mathrm{~kg} \mathrm{~N} / \mathrm{ha}$ (soil plus applied N) should be available at tuber initiation, with the remaining $\mathrm{N}$ applied via sprinkler irrigation prior to the last week of July. Nitrogen response studies conducted for 2 years at Aberdeen, Idaho indicate that petiole nitrate levels for Mountain Gem Russet grown for early fresh market should be about 18 , $000 \mathrm{ppm}$ at the end of tuber initiation and decrease to 12 , $000 \mathrm{ppm}$ during mid-bulking and about $8000 \mathrm{ppm}$ during late bulking.

\section{Late Harvest (Full Season) Production}

For late harvest production, seed spacing of 23 to $25 \mathrm{~cm}$ with rows spaced $91 \mathrm{~cm}$ apart is also recommended for either fresh market or processing. Seasonal soil plus fertilizer $\mathrm{N}$ rates should be increased to $200-220 \mathrm{~kg} \mathrm{~N} / \mathrm{ha}$ for a $45 \mathrm{t} / \mathrm{ha}$ yield potential, $240-260 \mathrm{~kg} \mathrm{~N} / \mathrm{ha}$ with a $56 \mathrm{t} / \mathrm{ha}$ yield potential, and $280-300 \mathrm{~kg} \mathrm{~N} / \mathrm{ha}$ in areas with a $67 \mathrm{t} /$ ha yield potential. Petiole nitrate levels for Mountain Gem Russet grown for late harvest production should be about $20,000 \mathrm{ppm}$ at the end of tuber initiation and decrease to 14,000 to $16,000 \mathrm{ppm}$ during mid-bulking decreasing to 10,000 ppm during late bulking.

Phosphorus, potassium and micronutrient requirements have not been established for Mountain Gem Russet. Therefore, it is recommended that growers follow local nutrient management recommendations for Russet Burbank (Stark et al., 2004) until new guidelines for Mountain Gem Russet become available. 
Irrigation Management Seasonal available soil moisture (ASM) should be maintained within the range of 70 to $85 \%$ for optimal yield and quality. Plant water uptake decreases appreciably in late August as vines senesce, so irrigation application rates need to be adjusted to maintain ASM at about 60 to $70 \%$ to avoid developing excessively wet soil conditions that promote disease and enlarged lenticels. Low soil moisture conditions appreciably below $60 \%$ ASM should be avoided during tuber maturation and harvest to minimize tuber dehydration and blackspot bruise. However, because of its susceptibility to shatter bruise, Mountain Gem Russet should be harvested with a moderate tuber hydration level.

Harvest Management Irrigation rates should be gradually reduced during the last 2 weeks prior to vine kill to allow tuber hydration to decrease to an intermediate level during skin set. Standard practices for minimizing tuber impact damage should be followed to reduce the potential for shatter bruise. Early blight control for tubers in fields scheduled for storage can be facilitated by minimizing tuber skinning and bruising during harvest and subsequent handling and avoiding harvesting in wet weather conditions.

\section{Columbia Basin of Washington}

When grown in the Columbia Basin of Washington, Mountain Gem Russet typically produces a medium to large tuber size profile, similar to Ranger Russet and slightly larger than Russet Burbank and Russet Norkotah. Five years of in-field testing in Othello, WA revealed that Mountain Gem Russet tends to produce slightly more tubers per plant $(\sim 0.6$ to 1.0$)$ than the same three varieties listed above. Agronomists should note that across the 5 years of evaluation in WA, hollow heart tended to be more serious when Mountain Gem Russet was planted early, before the middle of April, when compared with later planting dates. Due to tuber size profile similarities with Ranger Russet, we recommend Mountain Gem Russet seed pieces be planted in a spatial arrangement similar to that of Ranger Russet (recommendations shown below), regardless of market choice (fresh or process). Seed piece size should range from 43 to $85 \mathrm{~g}$, planted into rows spaced $87 \mathrm{~cm}$ apart.
Fig. 3 a and b. Tuber sucrose and glucose concentrations, and $\mathbf{c}$ fry colors (\% reflectance) of Mountain Gem Russet over a 3year period relative to Russet Burbank, following 0 to 250 days of storage at $5.6,7.2$, and $8.9^{\circ} \mathrm{C}$; tubers were from research plots at Kimberly, ID. These three storage temperatures reflect an initial storage of harvested tubers for 14 days at $12.8^{\circ} \mathrm{C}$ followed by an incremental lowering of the temperature by $0.28^{\circ} \mathrm{C}$ per day until the three storage temperatures were reached. Sugar concentrations and fry colors of Russet Burbank represent a 3 year average. Fry colors with Photovolt light reflectance readings of $\geq 35$ and USDA ratings of $\leq 2.0$ are considered acceptable. Storage periods for Mountain Gem Russet during 2013-2014 and 2014-2015 are represented as'13-14' and'14 14 ' at the bottom of the figure, while the storage periods for Russet Burbank during the 2013, 2014 and 2015 storage seasons are represented as' $13-15$ '
A

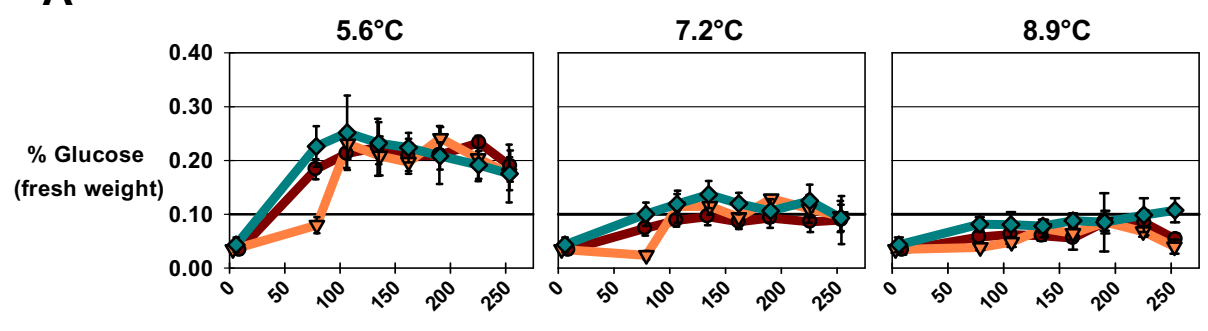

B
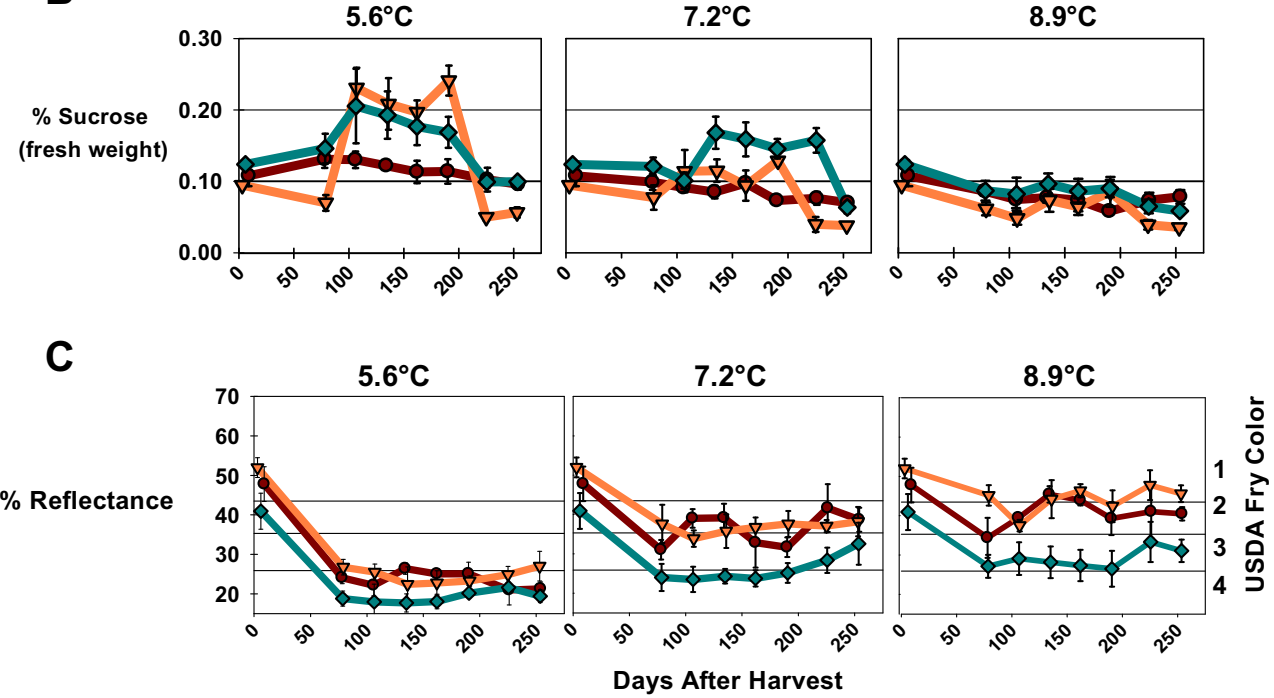

Mountain Gem

Russet Burbank

13-14 $\nabla$ 14-15

mean 13-15 
Recommended final planting depth is $20 \mathrm{~cm}$ from the top of the hill to the top of the planted seed piece.

\section{Early Harvest Production - Fresh and Process Markets}

Although Mountain Gem Russet is not an early-maturing variety based on vine senescence, it could be grown in the Columbia Basin for an early-to mid-season harvest, especially if the vines were removed prior to natural maturity. For an early-to mid-season harvest between mid-July and mid-August, [100-120 days after planting (DAP)], seed pieces should be spaced approximately $31 \mathrm{~cm}$ apart in-row; beyond 120 DAP, space $25 \mathrm{~cm}$ apart. Total seasonal $\mathrm{N}$ applications should be 180 to $250 \mathrm{~kg} \mathrm{~N} / \mathrm{ha}$, including pre-plant and residual inorganic soil $\mathrm{N}\left(\mathrm{NO}_{3}-\mathrm{N}\right.$ plus $\left.\mathrm{NH}_{4}-\mathrm{N}\right)$. A total of 140 to $170 \mathrm{~kg} \mathrm{~N} / \mathrm{ha}$ (residual soil $\mathrm{N}$ plus fertilizer $\mathrm{N}$ ) should be available in the root zone at emergence. The remaining $\mathrm{N}$ should be applied via overhead irrigation during tuber bulking. Adequate $\mathrm{N}$ should be applied to maintain petiole $\mathrm{NO}_{3}-\mathrm{N}$ concentrations at the end of tuber initiation (about $60 \mathrm{DAP}$ ) above 18,000 ppm and total inorganic soil N above $55 \mathrm{~kg} \mathrm{~N} / \mathrm{ha}$. During early bulking (about 80-90 DAP), petiole $\mathrm{NO}_{3}-\mathrm{N}$ concentrations should be about 15 , $000 \mathrm{ppm}$ and soil inorganic $\mathrm{N}$ should be below $55 \mathrm{~kg} \mathrm{~N} / \mathrm{ha}$. Petiole $\mathrm{NO}_{3}-\mathrm{N}$ should be allowed to decease to $<12,000 \mathrm{ppm}$ at mid- to late-bulking (approximately 100-110 DAP).

\section{Late Harvest (Full Season) Production - Fresh and Process Markets}

For full season growth with a harvest between mid-August and October ( $>130$ DAP), seed should be spaced $25 \mathrm{~cm}$ apart in-row. Nitrogen fertilizer management should be similar to the recommendations for early harvest-fresh market, with the exception that for harvest later than mid-September, growers should strive to keep their petiole $\mathrm{NO}_{3}-\mathrm{N}$ concentrations at the end of tuber initiation (about 60 DAP) above 22,000 ppm and total inorganic soil N above $100 \mathrm{~kg} \mathrm{~N} / \mathrm{ha}$, between 18,000 to $22,000 \mathrm{ppm}$ at early bulking (80-90 DAP) and between 8000 to $13,000 \mathrm{ppm}$ during late bulking (approximately $125 \mathrm{DAP}$ ).

Management guidelines for nutrients other than $\mathrm{N}$ have not been established for Mountain Gem Russet. Therefore, it is recommended that growers follow local nutrient management recommendations for Russet Burbank (Lang et al. 1999) until new guidelines for Mountain Gem Russet become available.

Irrigation Management Available soil moisture (ASM) should be maintained at 75 to $85 \%$ from full emergence until late bulking. As vines senesce, ASM should be reduced to 60 to $65 \%$. Avoid excessive soil moisture from mid to late bulking to minimize lenticel swelling. See Idaho recommendations above for additional irrigation and harvest management suggestions.

\section{Storage Management}

Mountain Gem Russet was tested in the UI Kimberly Potato Storage Trial during the 2013-14 storage seasons. Dormancy length of Mountain Gem Russet tubers is relatively short. Dormancy length across a range of storage temperatures was 120 days at $5.6^{\circ} \mathrm{C}, 90$ days at $7.2^{\circ} \mathrm{C}$, and 70 days at $8.9^{\circ} \mathrm{C}$. By comparison, dormancy length in Russet Burbank for the same years was 190 days at $5.6^{\circ} \mathrm{C}, 165$ days at $7.2^{\circ} \mathrm{C}$, and 140 days at $8.9^{\circ} \mathrm{C}$.

Percent glucose in Mountain Gem Russet tubers was similar to Russet Burbank at $5.6{ }^{\circ} \mathrm{C}$ storage (Fig. 3). At 7.2 and $8.9^{\circ} \mathrm{C}$, percent glucose was lower than $0.10 \%$ fresh weight and also was generally similar to Russet Burbank. Fry color values in Mountain Gem Russet tubers remained $\leq$ USDA 2 at $8.9^{\circ} \mathrm{C}$ throughout the 9 -month storage period. At $7.2^{\circ} \mathrm{C}$ fry color in Mountain Gem Russet ranged from USDA 2-3. At $5.6{ }^{\circ} \mathrm{C}$, average fry color in Mountain Gem Russet was USDA 4. By comparison, fry color in Russet Burbank tubers was $\geq$ USDA 4 at 5.6 and $7.2^{\circ} \mathrm{C}$, and a $\geq$ USDA 3 at $8.9{ }^{\circ} \mathrm{C}$ during the same storage time. Mottling, which is thin, thread-like areas of dark coloration found in the cortex of the fried potato tissue was mild to moderate in Mountain Gem Russet and similar to that of Russet Burbank. The mean percent weight loss over 9 months of storage at three temperatures was $10 \%$ in Mountain Gem Russet, which was not significantly different than Russet Burbank (8\%).

\section{Seed Availability}

In 2015, seed of Mountain gem Russet was available from potato seed growers in Idaho, Oregon, Montana and Nebraska. Small amounts of seed for research purposes can be obtained from the corresponding author. The University of Idaho, acting on behalf of the Potato Variety Management Institute has applied for Plant Variety Protection for Mountain Gem Russet.

Acknowledgments The authors thank Margaret Bain, Mel Chappell, Lorie Ewing, Nora Fuller, Mark Fristad, Darren Hall, Charlene Miller, Brian Schneider, Lura Schroeder, Steven Wheeler, and Todd Carter, as well as our collaborators in the Western Regional Potato Variety Trials, and the Idaho, Oregon and Washington Potato Commissions for their contributions to the development and release of Mountain Gem Russet. We also express thanks to our industry cooperators for their substantial contributions to this research effort. Development of Mountain Gem Russet was partially funded by USDA/NIFA.

\section{References}

Brown, C.R., H. Mojtahedi, G.S. Santo, P. Hamm, J.J. Pavek, D. Corsini, S. Love, J.M. Crosslin, and P.E. Thomas. 2000. Potato germplasm resistant to corky ringspot disease. American Journal of Potato Research 77: 23-27. 
Corsini, D., and J.J. Pavek. 1986. Fusarium dry-rot resistant potato germplasm. American Potato Journal 63: 629-638.

Corsini, D.L., J.J. Pavek, and J.R. Davis. 1988. Verticillium wilt resistance in non-cultivated tuber-bearing Solanum species. Plant Disease 75: 148-151.

Corsini, D.L., J.J. Pavek, M.W. Martin, and C.R. Brown. 1994. Potato germplasm with combined resistance to leafroll virus and viruses $\mathrm{X}$ and Y. American Potato Journal 71: 377-385.

Haynes, K.G., B.J. Christ, D.P. Weingartner, D.S. Douches, C.A. Thill, G. Secor, W.E. Fry, and D.H. Lambert. 2002. Foliar resistance to late blight in potato clones evaluated in national trials in 1997. American Journal of Potato Research 79: 451-457.

Haynes, K.G., L.A. Wanner, C.A. Thill, J.M. Bradeen, J. Miller, R.G. Novy, J.L. Whitworth, D.L. Corsini, and B.T. Vinyard. 2010. Common scab trials of potato varieties and advanced selections at three U.S. locations. American Journal of Potato Research 87: 261276.
Lang, N.S., R.G. Stevens, R.E. Thornton, W.L. Pan, and S. Victory. 1999. Nutrient Management Guide: Central Washington Irrigated Potatoes. Washington State University Experiment Station Extension Bulletin EB1882.

Love, S.L., T. Salaiz, B. Shafii, W.J. Price, A.R. Mosley, and R.E. Thornton. 2004. Stability of expression and concentration of ascorbic acid in North American potato germplasm. HortScience 39(1): $156-160$.

Mosley, A., S. Yilma, D. Hane, S. James, K. Rykbost, C. Shock, B. Charlton, E. Eldredge, and L. Leroux. 2003. Oregon. In: K. G. Haynes (ed), National Potato Germplasm Evaluation and Enhancement Report, 2001. pp. 369-388.

Stark J, D Westermann, and B Hopkins. 2004. Nutrient management guidelines for Russet Burbank potatoes. University of Idaho Extension Bulletin No. 840, 12 p. 